\title{
Effect of Seeding Rate for Mat type Nursery on growth, Yield and Economic Efficacy of Mechanically Transplanted Fine Basmati Rice
}

\author{
Ali Zohaib*, Muzzammil Hussain, Iftikhar Ahmad and Adnan Bashir
}

Adaptive Research Farm, Gujranwala 52200, Pakistan.

\begin{abstract}
Mechanical transplanting with mat type nursery is quite a new planting technique for rice. However, optimization of seeding rate for producing mat type nursery is crucial to acquire suitable seedlings and planting density for better yield of mechanically transplanted rice (MTR). Current 2-years field study was conducted to determine effect of seeding rate $(80,90,100$ and $110 \mathrm{~g}$ per tray) for preparing nursery mats of fine basmati rice on plant growth, grain yield and economic benefits. Seeding rate significantly affected the growth, yield and related traits of fine basmati rice. Increase in seeding rate from 80 to $110 \mathrm{~g}$ per tray successively increased number of plants per tray and per hill after transplanting while decreased the root length and root/ shoot ratio of rice. Plant height was not affected significantly by seeding rate. Highest increase in number of productive tillers (8\%), 1000-grain weight (8\%), total dry biomass (14-17\%) and grain yield (10-16\%) was caused by $90 \mathrm{~g}$ seed per tray, as compared to $110 \mathrm{~g}$ seed per tray. Order of grain yield produced by different seeding rates was $90>80>100>110 \mathrm{~g}$ per tray. Economic analysis exhibited that maximum net returns and benefit cost ratio (BCR) was achieved by using $90 \mathrm{~g}$ seed per tray. In conclusion, $90 \mathrm{~g}$ seed per tray improved the grain yield by enhancing number of productive tillers and grain weight of fine basmati rice; hence, could be adopted for better productivity and economic benefits of mechanically transplanted fine basmati rice.

Received | May 06, 2021; Accepted | November 12, 2021; Published | January 19, 2022

*Correspondence | Ali Zohaib, Adaptive Research Farm, Gujranwala 52200, Pakistan; Email: alizohaib208@gmail.com

Citation | Zohaib, A., M. Hussain, I. Ahmad and A. Bashir. 2020. Effect of seeding rate for mat type nursery on growth, yield and economic efficacy of mechanically transplanted Fine Basmati Rice. Pakistan Journal of Agricultural Research, 35(1): 21-28.

DOI | https://dx.doi.org/10.17582/journal.pjar/2022/35.1.21.28

Keywords | Biomass accumulation, Economic benefits, Plant growth, Mechanical rice transplanting, Yield
\end{abstract}

\section{Introduction}

$\mathrm{R}$ ice (Oryza sativa L.) is utilized as staple food in many countries of the world and in Pakistan after wheat. Various management factors greatly affect its yield including planting method (Rani and Jayakiran, 2010). Rice is planted by different methods viz. conventional (manual transplanting), and simplified and mechanized (direct seeding, mechanical transplanting) (Ehsanullah et al., 2007; Bian et al., 2018). Conventional method of rice transplanting is quite laborious, expensive and time consuming. Moreover, unskilled laborer retains the plant population less than optimum required due to uneven plant spacing which results in yield reductions and economic losses (Mann and Ashraf, 2001; Rani and Jayakiran, 2010). Hence, the arising circumstances of labor scarcity, low plant population, low yield and increasing cost of production has led to conversion from conventional planting method to mechanical transplanting of rice (Shinde et al., 2018).

Mechanical rice transplanting ensures timely sowing of optimal aged seedlings which consequences in production of more productive tillers while avoids shortened period of vegetative growth and decreased dry matter accumulation thereby increasing crop yield (Malik et al., 2011; Liu et al., 2015). Moreo- 
ver, in MTR seedlings are transplanted having soil attached to the roots and without breaking the roots which avoid early transplanting shock, and uniform plant spacing ensures optimum plant population as well thereby improving the grain yield (Malik et al., 2011). However, management of seeding rate and proper plant density is essential for getting better yield of MTR (Yu et al., 2006; Liu et al., 2017). Plant density has established role in manipulating population characteristics ( $\mathrm{Li}$ et al., 2016), regulation of tiller production (Huang et al., 2013), radiation use efficiency (Chen et al., 2019), photo-assimilation and yield formation (Nakano et al., 2012).

In MTR, optimum seeding rate is essential for acquiring better quality seedlings and their establishment after transplanting, optimum plant population and plants per hill, improved subsequent plant growth and crop productivity (Hossen et al., 2018). Low seeding rate produces superior quality seedlings but the twisting roots remain unable to curl up for mechanical transplanting. Moreover, low seeding rate produce less seedlings per tray which results in greater number of missing hills and low plant population per unit area (Yu et al., 2006; Hossen et al., 2018). Conversely, high seeding rate increases the plant population and plants per hill but produces poor quality seedlings (Yu et al., 2006; Hossen et al., 2018). Nonetheless, the seeding rate per unit area varies for coarse and fine types of rice (Dongarwar et al., 2018). Similarly, seeding rate in MTR also varies for short, medium and long rice types (Hossen et al., 2018). Hence, optimization of seeding rate for mechanically transplanted fine basmati rice is essential for acquiring optimum plant population and grain yield.

Mechanical transplanting of rice provides an alternative solution of labor shortage, and produces high yield due to optimum plant population and avoiding transplanting shock in comparison with conventional transplanting. Seeding rate per tray is important for attaining better quality seedlings, and optimum plant population and plants per hill in MTR. However, to best of our knowledge information is scarce regarding seeding rate of fine basmati rice for mechanical transplanting. It was hypothesized that proper seeding rate will produce optimum plant population and plants per hill, better growth and ultimately yield of mechanically transplanted fine basmati rice. This two years field study was conducted with objectives to ascertain influence of seeding rate per tray on growth, grain yield and economic benefits of mechanically transplanted fine basmati rice.

\section{Materials and Methods}

\section{Experimental details}

Experiment was performed at Adaptive Research Farm, Gujranwala, Pakistan $\left(32^{\circ} 12^{\prime} 15^{\prime \prime} \mathrm{N} 74^{\circ} 13^{\prime} 48^{\prime \prime} \mathrm{E}\right.$ and $227 \mathrm{~m}$ above sea level) during 2019 and 2020. Soil samples were collected from experimental field (0-30 $\mathrm{cm}$ depth) to analyze for physico-chemical characteristic. Working soil samples were drawn out of composite samples and submitted to Soil and Water Testing Laboratory, Gujranwala for analysis. The soil was heavy loam, having organic matter (0.91\%), $\mathrm{pH}(7.6)$, electrical conductivity $(1.3 \mathrm{mS} / \mathrm{cm})$, total $\mathrm{N}$ (0.05), available P (10.5 ppm) and available K (142 ppm). Experiment was conducted by using the Randomized complete block design with three replications. The area of net plot was $15 \mathrm{~m} \times 12 \mathrm{~m}$. Treatments were comprised of different seeding rates including 80, 90, 100 and $110 \mathrm{~g}$ seed per tray. Meteorological data prevailed during experimental period is presented in Table 1.

Table 1: Meteorological conditions during rice growing seasons.

\begin{tabular}{|c|c|c|c|c|c|c|c|c|c|c|}
\hline \multirow[t]{3}{*}{ Month } & \multirow{2}{*}{\multicolumn{2}{|c|}{$\begin{array}{l}\text { Total Rainfall } \\
(\mathrm{mm})\end{array}$}} & \multirow{2}{*}{\multicolumn{2}{|c|}{$\begin{array}{l}\text { Relative Humidity } \\
(\%)\end{array}$}} & \multicolumn{6}{|c|}{ Temperature $\left({ }^{\circ} \mathrm{C}\right)$} \\
\hline & & & & & \multicolumn{2}{|c|}{ Monthly Maximum } & \multicolumn{2}{|c|}{ Monthly Minimum } & \multicolumn{2}{|c|}{ Daily Mean } \\
\hline & 2019 & 2020 & 2019 & 2020 & 2019 & 2020 & 2019 & 2020 & 2019 & 2020 \\
\hline June & 96.5 & 97.6 & 74.3 & 75.1 & 37.5 & 37.5 & 25.3 & 23.9 & 31.4 & 30.7 \\
\hline July & 240.0 & 79.6 & 82.4 & 80.3 & 39.3 & 35.9 & 25.5 & 26.5 & 32.4 & 31.2 \\
\hline August & 138.3 & 333.3 & 85.7 & 89.5 & 36.1 & 34.3 & 27.2 & 26.5 & 31.7 & 30.4 \\
\hline September & 52.9 & 49.2 & 84.1 & 85.4 & 34.9 & 36.1 & 24.7 & 25.0 & 29.8 & 30.6 \\
\hline October & 28.9 & 0.0 & 83.4 & 82.2 & 31.5 & 33.6 & 17.9 & 17.7 & 24.7 & 25.6 \\
\hline November & 17.3 & 15.5 & 85.2 & 84.3 & 24.6 & 24.8 & 13.3 & 10.8 & 19.0 & 17.8 \\
\hline
\end{tabular}

Source: Meteorological Department, Punjab 
Crophusbandry

Fine basmati rice cultivar Super basmati was used for conducting experiment. The nursery was sown in trays $(60 \mathrm{~cm} \times 30 \mathrm{~cm} \times 2.5 \mathrm{~cm})$ to prepare the mats on $14^{\text {th }}$ and $25^{\text {th }}$ June during 2019 and 2020, respectively using seeding rates according to treatments. The soil was puddled and nursery was transplanted using four row walk after type mechanical transplanting machine in standing water up to a depth of $2.5 \mathrm{~cm}$ on $14^{\text {th }}$ and $25^{\text {th }}$ July during 2019 and 2020, respectively. Inter and intra row plant spacing was kept 25 and $20 \mathrm{~cm}$, respectively. The fertilization was carried out at the rate of $120-88-62 \mathrm{~kg} / \mathrm{ha}$ NPK. Complete $\mathrm{P}, \mathrm{K}$, and one-third of $\mathrm{N}$ was applied at transplanting while left over $\mathrm{N}$ was split applied at 30 and 45 days after transplanting (DAT). Zinc sulfate (33\%) was utilized at application rate of $15 \mathrm{~kg} \mathrm{ha}{ }^{-1}, 10$ DAT. Water was kept standing in field at $5 \mathrm{~cm}$ depth up to 25 days. After that irrigation was applied just to keep soil moistened and halted 15 days prior to harvesting. Plant protection was accomplished using local recommendations. The crop was harvested manually in first week of November and threshed by beating against drums during both years.

\section{Measurements}

Plants from nine selected trays were counted after completion of emergence to determine the number of plants per tray. Average number of plants transplanted per hill was determined by calculating number of plants $\mathrm{m}^{-2}$ and dividing with number of hills $\mathrm{m}^{-2}$. At harvest, data were collected regarding growth and yield traits. The plant height of randomly selected four plants was measured with meter rod and averaged. Root length was determined without uprooting the plants by digging but instead sliced the soil along the selected plants until full depth of roots was achieved, and measured using meter rod and averaged. Root/shoot ratio was determined by dividing the root length with plant height. Number of productive tillers $\mathrm{m}^{-2}$ and hill ${ }^{-1}$ was ascertained by counting productive tillers from one $\mathrm{m}^{2}$ area and dividing with number of hills $\mathrm{m}^{-2}$, respectively. Grains obtained from selected plants were counted and averaged to determine number of grains per panicle. The 1000-grain weight was determined by counting and weighing the grains with electric balance. Plants harvested from selected area were weighed before threshing, sub-samples drawn, dried and weighed again to determine total dry biomass, and expressed as $\mathrm{t} \mathrm{ha} \mathrm{h}^{-1}$. Grain yield was ascertained by manually threshing the harvested plants and weighing grains, and expressed as $\mathrm{tha}^{-1}$.

\section{Economic analyses}

Total cost, net returns and BCR was determined by adopting the methods described CIMMYT (1988). Fixed cost was determined by summing prices of all used inputs. Variable cost was comprised of cost of seed used in each treatment. Total cost was computed by summing the fixed and variable cost. Net returns were computed by utilizing formula;

Net returns $=$ gross income - total cost. The BCR was calculated by using formula; $B C R=$ (Gross income $/$ total cost).

\section{Statistical analyses}

Data were tested for normality with scatter plot technique. The data were normal and analyzed using the analysis of variance (ANOVA) technique (Steel et al., 1997). Comparison of treatments' means was carried out by using the least significant difference (LSD) test at $5 \%$ probability.

\section{Results and Discussion}

\section{Plant population and growth attributes}

Seeding rate significantly affected the number of plants per tray and per hill after transplanting, root length and root/shoot ratio of rice during both years. However, the influence of seeding rate on number of hills $\mathrm{m}^{-2}$ and plant height was found non-significant, during both years. Highest number of plants per tray (2574 and 2625) and number of plants per hill after transplanting (3.39 and 3.52) were recorded by increasing the seeding rate up to $110 \mathrm{~g}$ per tray during both years. On the other hand, the maximum root length and root/shoot ratio was achieved at low seeding rate and decreased with increase in seeding rate. The greatest increase in root length (12-17\%) and root/shoot ratio (13-17\%) was noticed by using $80 \mathrm{~g}$ seed per tray as compared to $110 \mathrm{~g}$ seed per tray, during both years; however, $90 \mathrm{~g}$ seed per tray gave similar root length and root/shoot ratio during both years (Tables 2 and 3 ).

In present study the number of plants of rice per tray and average number of plants per hill after transplanting were increased by increasing the seeding rate (Table 2). Similarly, Hossen et al. (2018) reported that increase in seeding rate per tray increased the number of seeds and plants but decreased the emergence percentage. In present study, root length and root/shoot ratio of rice were decreased with increase in seeding 
Table 2: Effect of seeding rate on number of plants and hills of mechanically transplanted rice.

\begin{tabular}{|c|c|c|c|c|c|c|}
\hline \multirow{2}{*}{ Seed rate $\left(\mathrm{g}\right.$ tray $\left.^{-1}\right)$} & \multicolumn{2}{|c|}{ No. of plants tray ${ }^{-1}$} & \multicolumn{2}{|c|}{ No. of hills $\mathrm{m}^{-2}$} & \multicolumn{2}{|c|}{ No. of plants hill-1 } \\
\hline & 2019 & 2020 & 2019 & 2020 & 2019 & 2020 \\
\hline 80 & $1372 \mathrm{~d}$ & $1389 \mathrm{~d}$ & 18.0 & 17.7 & $1.91 \mathrm{~d}$ & $1.97 \mathrm{~d}$ \\
\hline 90 & $1840 \mathrm{c}$ & $1804 \mathrm{c}$ & 18.0 & 18.0 & $2.56 \mathrm{c}$ & $2.51 \mathrm{c}$ \\
\hline 100 & $2172 \mathrm{~b}$ & $2198 \mathrm{~b}$ & 18.7 & 18.7 & $2.91 \mathrm{~b}$ & $2.94 \mathrm{~b}$ \\
\hline 110 & $2574 \mathrm{a}$ & $2625 \mathrm{a}$ & 19.0 & 18.7 & $3.39 \mathrm{a}$ & $3.52 \mathrm{a}$ \\
\hline $\operatorname{LSD}_{\mathrm{P}<0.05}$ & 87.372 & 79.998 & ns & $\mathrm{ns}$ & 0.226 & 0.234 \\
\hline
\end{tabular}

Means in a column having same letters don't differ significantly at $P<0.05$

Table 3: Effect of seeding rate on plant growth of mechanically transplanted rice.

\begin{tabular}{llllll} 
Plant height $(\mathbf{c m})$ & \multicolumn{2}{l}{ Root length $(\mathbf{c m})$} & \multicolumn{2}{l}{ Root/shoot ratio } \\
2019 & 2020 & 2019 & 2020 & 2019 & $\mathbf{2 0 2 0}$ \\
116.67 b & 115.00 a & 38.50 a & 37.18 a & 0.33 a & 0.32 a \\
119.33 a & 116.67 a & 38.18 a & 36.16 ab & 0.32 ab & 0.31 ab \\
117.67 a & 116.00 a & 35.69 b & 33.62 bc & 0.30 bc & 0.29 bc \\
117.00 a & 115.00 a & 34.31 b & 31.80 c & 0.29 c & 0.28 c \\
ns & ns & 1.862 & 2.664 & 0.018 & 0.030
\end{tabular}

Means in a column having same letters don't differ significantly at $P<0.05$

rate although plant height was not affected significantly (Table 3). This decrease is attributed to greater competition among plants due to more seedlings per hill at high seeding rates (Table 2). Deng et al. (2020) observed that increasing the plant density by seeding rate while keeping the inter-row plant spacing fixed but not caring of intra-row plant spacing in direct seeded rice resulted in improved root growth. However, Wang et al. (2010) observed that increasing the number of seedlings per hill without variation in hills per unit area in transplanted rice increased the dry matter partitioning to the above ground plant parts more than roots. Similarly, in present study, the plants of MTR per hill were increased by increasing the seeding rate per tray which might have decreased the root growth at higher seeding rates (Tables 2 and 3).

\section{Grain yield and related attributes}

Number of productive tillers $\mathrm{m}^{-2}$ and hill-1 (Table 4), total dry biomass (Figure $1 \mathrm{a}, \mathrm{b}$ ) and grain yield of rice (Figure $2 \mathrm{a}, \mathrm{b}$ ) was significantly affected by seeding rate during both years. However, seeding rate didn't affect significantly the number of grains per panicle during both years and 1000-grain weight during 2019 (Table 4). Grain yield and related attributes of rice were higher at lower seeding rate when compared with higher seeding rate (Table 4, Figure 2 a,b). Maximum increase in number of productive tillers $\mathrm{m}^{-2}(8 \%)$ was caused by $90 \mathrm{~g}$ seed per tray while number of productive tillers hill $^{-1}(12-13 \%)$ was increased the most by $80 \mathrm{~g}$ seed per tray, as compared to $110 \mathrm{~g}$ seed per tray, during both years. The 1000-grain weight was higher by $8 \%$ in response to $90 \mathrm{~g}$ seed per tray, as compared to $110 \mathrm{~g}$ seed per tray and it was followed by $100 \mathrm{~g}$ seed per tray, during 2020 (Table 4). Exaggeration in total dry biomass (14-17\%) and grain yield (10-16\%) of rice was occurred by $90 \mathrm{~g}$ seed per tray, as compared to $110 \mathrm{~g}$ seed per tray and it was followed by $80 \mathrm{~g}$ seed per tray, during both years (Figures $1 \mathrm{a}, \mathrm{b}$ and $2 \mathrm{a}, \mathrm{b}$ ).

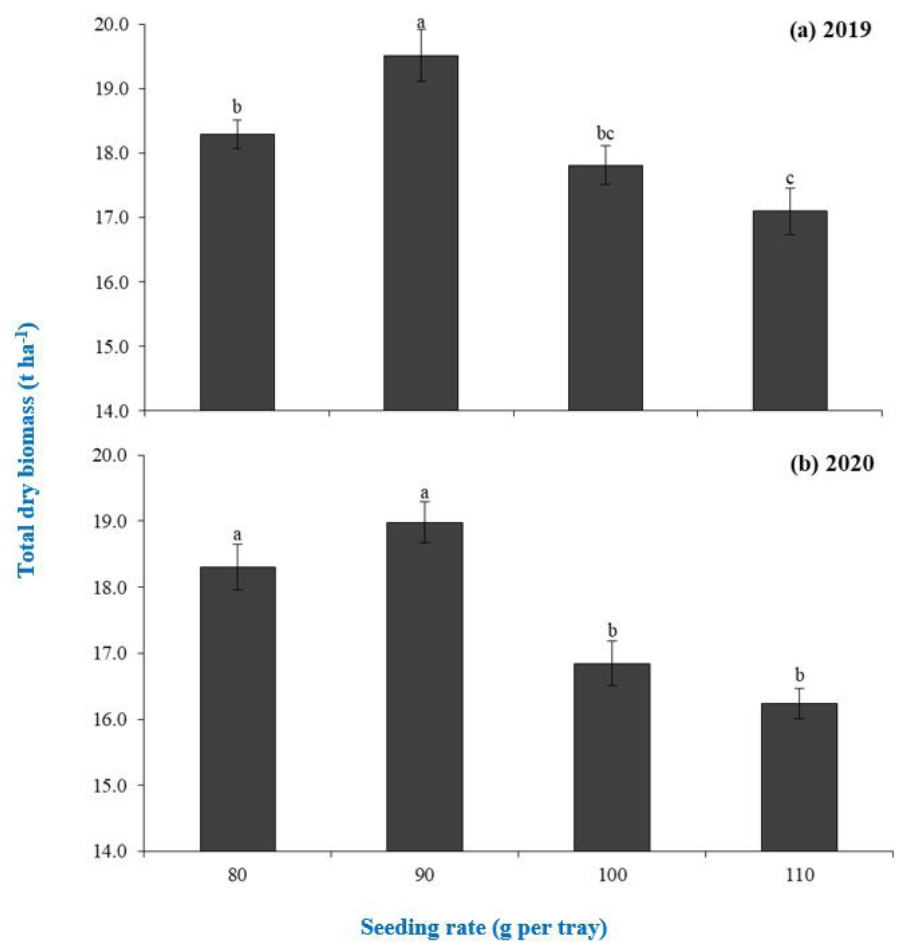

Figure 1: Effect of seeding rate on total dry biomass of mechanically transplanted rice during (a) 2019 and (b) 2020; Bars are mean \pm SE $(n=3)$. Bars sharing same letter don't differ significantly at $P<0.05$.

In present study, maximum productive tillers per hill were exhibitedd by $80 \mathrm{~g}$ seed per tray while productive tillers $\mathrm{m}^{-2}$ were the highest by $90 \mathrm{~g}$ seed per tray ( $\mathrm{Ta}-$ ble 4) due to higher missing hills in $80 \mathrm{~g}$ seed per tray (Table 2). However, seeding rate higher than $90 \mathrm{~g}$ per 
Table 4: Effect of seeding rate on yield related attributes of mechanically transplanted rice.

\begin{tabular}{|c|c|c|c|c|c|c|c|c|}
\hline \multirow{2}{*}{$\begin{array}{l}\text { Seed rate }(g \\
\left.\text { tray }^{-1}\right)\end{array}$} & \multicolumn{2}{|c|}{ No. of productive tillers $\mathrm{m}^{-2}$} & \multicolumn{2}{|c|}{ No. of productive tillers hill ${ }^{-1}$} & \multicolumn{2}{|c|}{ No. of grains panicle ${ }^{-1}$} & \multicolumn{2}{|c|}{1000 -grain weight $(\mathrm{g})$} \\
\hline & 2019 & 2020 & 2019 & 2020 & 2019 & 2020 & 2019 & 2020 \\
\hline 80 & $348 \mathrm{a}$ & $344 a$ & $19.37 \mathrm{a}$ & $19.54 \mathrm{a}$ & $102.33 \mathrm{a}$ & $111.33 \mathrm{a}$ & $22.00 \mathrm{a}$ & $22.17 \mathrm{ab}$ \\
\hline 90 & $349 \mathrm{a}$ & $351 \mathrm{a}$ & $19.37 \mathrm{a}$ & $19.48 \mathrm{a}$ & $102.33 \mathrm{a}$ & $110.33 \mathrm{a}$ & $22.67 \mathrm{a}$ & $23.50 \mathrm{a}$ \\
\hline 100 & $335 \mathrm{ab}$ & $328 \mathrm{~b}$ & $17.97 \mathrm{ab}$ & $17.58 \mathrm{~b}$ & $103.67 \mathrm{a}$ & $109.67 \mathrm{a}$ & $21.33 \mathrm{a}$ & $22.50 \mathrm{a}$ \\
\hline 110 & $324 \mathrm{~b}$ & $325 \mathrm{~b}$ & $17.07 \mathrm{~b}$ & $17.43 \mathrm{~b}$ & $102.67 \mathrm{a}$ & $108.33 \mathrm{a}$ & $22.00 \mathrm{a}$ & $21.83 \mathrm{~b}$ \\
\hline $\mathrm{LSD}_{\mathrm{P}<0.05}$ & 14.776 & 12.176 & 1.479 & 1.297 & ns & ns & ns & 1.141 \\
\hline
\end{tabular}

Means in a column having same letters don't differ significantly at $P<0.05$

Table 5: Effect of seeding rate on economic efficiency of mechanically transplanted rice.

\begin{tabular}{|c|c|c|c|c|c|c|c|c|c|c|c|c|}
\hline \multirow[t]{2}{*}{$\begin{array}{l}\text { Seed rate }(\mathrm{g} \\
\left.\text { tray }^{-1}\right)\end{array}$} & \multicolumn{2}{|c|}{$\begin{array}{l}\text { Adjusted Grain } \\
\text { yield (t/ha) }\end{array}$} & \multicolumn{2}{|c|}{$\begin{array}{l}\text { Gross income (Rs/ } \\
\text { ha) }\end{array}$} & \multicolumn{2}{|c|}{$\begin{array}{l}\text { Variable cost } \\
\text { (Rs/ha) }\end{array}$} & \multicolumn{2}{|c|}{ Total Cost (Rs/ha) } & \multicolumn{2}{|c|}{ Net returns (Rs/ha) } & \multicolumn{2}{|c|}{$\begin{array}{l}\text { Benefit cost } \\
\text { ratio }\end{array}$} \\
\hline & 2019 & 2020 & 2019 & 2020 & 2019 & 2020 & 2019 & 2020 & 2019 & 2020 & 2019 & 2020 \\
\hline 80 & 4.00 & 3.98 & 243693 & 232870 & 3000 & 3000 & 119365 & 124188 & 124328 & 108683 & 2.04 & 1.88 \\
\hline 90 & 4.21 & 4.26 & 255768 & 247885 & 3375 & 3375 & 119740 & 124563 & 136028 & 123323 & 2.14 & 1.99 \\
\hline 100 & 3.93 & 3.77 & 239553 & 221155 & 3750 & 3750 & 120115 & 124938 & 119438 & 96218 & 1.99 & 1.77 \\
\hline 110 & 3.81 & 3.68 & 232998 & 216370 & 4125 & 4125 & 120490 & 125313 & 112508 & 91058 & 1.93 & 1.73 \\
\hline
\end{tabular}

Adjusted grain yield: 10\% less than actual grain yield; Cost and income was estimated by using the prevailing market prices for inputs and paddy, respectively, in Pakistan.

tray increased the plant population (Table 2) but reduced productive tillers hill-1 ${ }^{-1}$ and $\mathrm{m}^{-2}$ (Table 4). Productive tillers per unit area are decreased at high plant population because most of the tillers remain infertile possibly due to smaller tiller size and lower nitrogen content in plants (Hayashi et al., 2006). In present study, the grains per panicle of rice were not affected significantly while grain weight was significantly higher at lower seeding rates (Table 4). This might be explained on the basis of trade-off relationship between productive tillers, grains number and grain weight (Wang et al., 2014). Lower seeding rates produce sparse plant populations but higher productive tillers which don't allow the plants to produce more grains per panicle of rice; however, plants compensate this by enhancing grain filling rate (Gravios and Helms, 1992; Shu et al., 2009). Previous studies have reported similar results pertaining to the effect of seeding rate on yield attributes (Sarwar et al., 2011; Cui et al., 2014).

In current study, total dry biomass and grain yield of MTR was greater with lower seeding rate (i.e. $90 \mathrm{~g}$ per tray followed by $80 \mathrm{~g}$ per tray) as compared to higher seeding rate (Figures $1 \mathrm{a}, \mathrm{b}$ and $2 \mathrm{a}, \mathrm{b}$ ). The greater yield with low seeding rate was related with greater number of productive tillers and grain weight of rice (Table 4). Mechanically transplanted rice with lower seeding rates had less number of plants per hill than high seeding rates which might have improved the total dry biomass and grain yield due to better root morphological indices and less inter-plant competition (Wang et al., 2010; Yang et al., 2012). Previous studies have reported similar findings that low seeding rate and/or fewer seedlings per hill had better biomass and grain yield than higher number of seedlings per hill owing to less productive tillers, grains per panicle and grain weight (Srinivasulu et al., 1999; Ottis and Talbert, 2005; Baloch et al., 2006).

\section{Economic efficiency}

The economic analyses revealed that highest variable and total cost was incurred when $110 \mathrm{~g}$ seed per tray was used while minimum costs were observed for 80 $\mathrm{g}$ seed per tray during both years. However, highest gross income (Rs. 255768 and 247885), net returns (Rs. 136028 and 123323) and BCR (2.14 and 1.99) was obtained by using $90 \mathrm{~g}$ seed per tray (during 2019 and 2020, respectively). The order of BCR for different seeding rates was $90>80>100>110 \mathrm{~g}$ seed per tray during both years (Table 5).

In present study, it was noticed that increasing the seeding rate caused an increase in cost but the net returns and BCR was decreased as compared to lower seeding rates. However, highest net returns and BCR was recorded by using $90 \mathrm{~g}$ seed per tray which was associated with better grain yield (Figure 2 a,b) and 
hence gross income (Table 5). Previous studies have reported that aside from sowing method of rice the optimum seeding rate enhances the grain yield which ensues in higher economic returns and BCR, minimize economic losses and hence must be adopted to enhance crop productivity and economic benefits (Corbin et al., 2016; Dongarwar et al., 2018; Li et al., 2020).

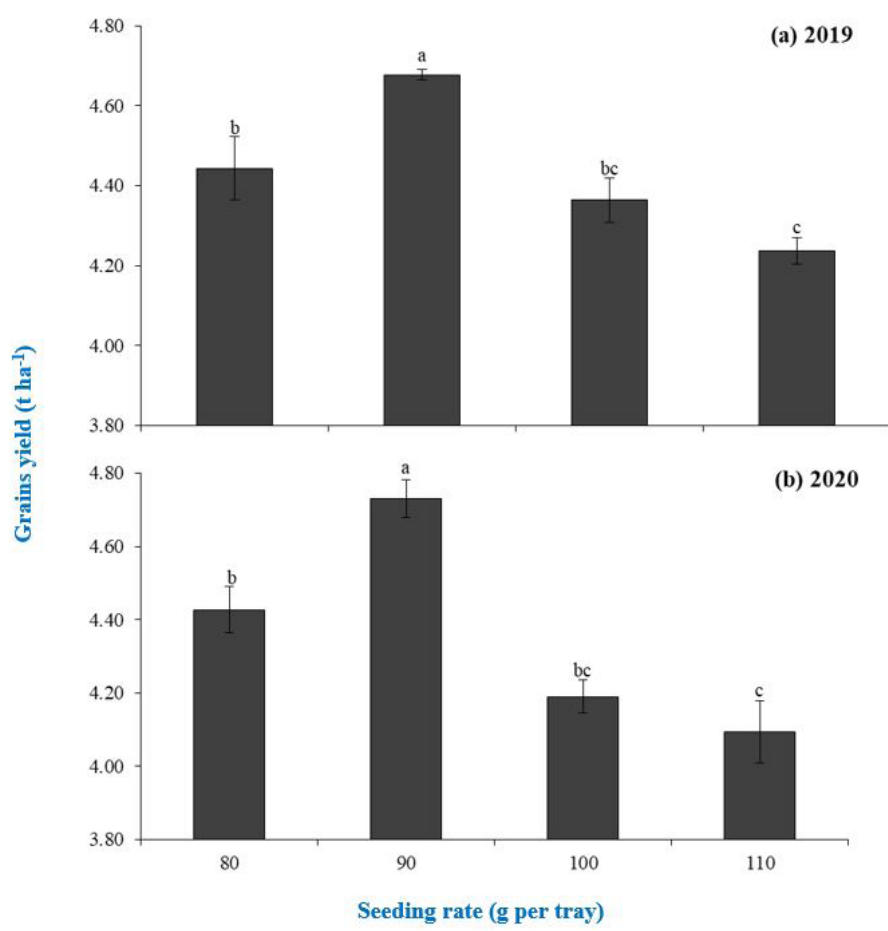

Figure 2: Effect of seeding rate on grain yield of mechanically transplanted rice during (a) 2019 and (b) 2020; Bars are mean \pm SE (n $=3)$. Bars sharing same letter don't differ significantly at $P<0.05$.

\section{Conclusions and Recommendations}

Seeding rate per tray of rice significantly affected the plant population, growth and yield. Optimum plant population, and maximum root growth, number of tillers, grain weight, dry biomass and grain yield was produced with lower seeding rates (specifically $90 \mathrm{~g}$ ) than higher seeding rates per tray. In conclusion, 90 $\mathrm{g}$ seed per tray improved the grain yield by enhancing number of productive tillers and grain weight of fine basmati rice; hence, could be adopted for better productivity and economic benefits of mechanically transplanted fine basmati rice.

\section{Novelty Statement}

Seeding rate is imperative to produce mat type nursery for mechanically transplanted rice and achieve vigorous seedlings and optimum planting density in order to obtain better yield. Current study was per- formed to optimize seeding rate of fine basmati rice per tray for better plant growth, grain yield and economic benefits.

\section{Author's Contribution}

Ali Zohaib: Planned and performed experiment, performed statistical and economic analyses, carried out write up and overall management of paper.

Muzzammil Hussain: Gave technical input at every step.

Iftikhar Ahmad: Supervised the study. Adnan Bashir managed crop in field.

\section{Conflict of Interest}

The authors have declared no conflict of interest.

\section{References}

Baloch, M.S., I.U. Awan and G. Hassan. 2006. Growth and yield of rice as affected by transplanting dates and seedlings per hill under high temperature of Dera Ismail Khan, Pakistan. J. Zhejiang Uni. Sci. B., 7(7): 572579. https://doi.org/10.1631/jzus.2006.B0572

Bian,J., F. Xu, C. Han, S. Qiu, J. Ge,J.Xu, H. Zhang and H. Wei. 2018. Effects of planting methods on yield and quality of different types of japonica rice in northern Jiangsu plain, China. J. Integr. Agric., 17(12): 2624-2635. https://doi. org/10.1016/S2095-3119(18)62141-0

Chen, S., M. Yin, X. Zheng, S. Liu, G. Chu, C. Xu, D. Wang and X. Zhang. 2019. Effect of dense planting of hybrid rice on grain yield and solar radiation use in southeastern China. Agron. J., 111(3): 1229-1238. https://doi.org/10.2134/ agronj2018.07.0430

CIMMYT. 1988. From Agronomic Data to Farmers Recommendations: An Economics Training Manual. Completely revised edition. Mexico DF.

Corbin, J.L., J.M. Orlowski, D.L. Harrell, B.R. Golden, L. Falconer, L.J. Krutz, J. Gore, M.S. Cox and T.W. Walker. 2016. Nitrogen strategy and seeding rate affect rice lodging, yield, and economic returns in the midsouthern United States. Agron. J., 108(5): 1938-1943. https:// doi.org/10.2134/agronj2016.03.0128

Cui,S.,G.Cao,W.Zhang and X.Zhu.2014.Suitable mechanical transplanting spacing promoting rice growth and increasing rice yield. Transact. 
Chinese Soc. Agric. Eng., 30(22): 37-43.

Deng, J., X. Feng, D. Wang, J. Lu, H. Chong, C. Shang, K. Liu, L. Huang, X. Tian and Y.Zhang. 2020. Root morphological traits and distribution in direct-seeded rice under dense planting with reduced nitrogen. Plos one, 15(9): e0238362. https://doi.org/10.1371/journal.pone.0238362

Dongarwar, U.R., N. Patke, L.N. Dongarwar and S.R. Kashiwar. 2018. Impact of different seed rates on yield and economics of direct seeded rice in eastern Vidharbha zone of Maharashtra, India. Int.J. Curr. Microbiol. App. Sci., 7(3): 32-42. https://doi.org/10.20546/ ijcmas.2018.703.004

Ehsanullah, N.Akbar, K.Jabran and M.Tahir.2007. Comparison of different planting methods for optimization of plant population of fine rice (Oryza sativa L.) in Punjab (Pakistan). Pak. J. Agric. Sci., 44: 597-599.

Gravios, K.A. and R.S. Helms. 1992. Path analysis of rice yield and yield components as affected by seeding rate. Agron. J., 84: 1-4. https://doi. org/10.2134/agronj1992.00021962008400010 $001 \mathrm{x}$

Hayashi, S., A. Kamoshita and J. Yamagishi. 2006. Effect of planting density on grain yield and water productivity of rice (Oryza sativa L.) grown in flooded and non-flooded fields in Japan. Plant prod. Sci., 9(3): 298-311. https:// doi.org/10.1626/pps.9.298

Hossen, M.A., M.M. Hossain, M.E., Haque and R.W. Bell. 2018. Effect of seed rate on seedling quality for mechanical rice transplanting. Bang. Rice J., 22: 9-23. https://doi.org/10.3329/brj. v22i1.41834

Huang, M., C. Yang, Q.Ji, L.Jiang,J.Tan and Y.Li. 2013. Tillering responses of rice to plant density and nitrogen rate in a subtropical environment of southern China. Field Crops Res., 149: 187192. https://doi.org/10.1016/j.fcr.2013.04.029

Li, G., J. Zhang, C. Yang, Z. Liu, S. Wang and Y. Ding. 2016. Population characteristics of highyielding rice under different densities. Agron. J., 108(4):1415-1423. https://doi.org/10.2134/ agronj2015.0214

Li, X., F. Dou, K.B. Watkins, S. Wang, K. Chen, X.G.Zhou, A.McClung,J.O. Storlien and F.M. Hons. 2020. Seeding rate effects on organic rice growth, yield, and economic returns. Agron. J., 112(5): 4104-4119. https://doi.org/10.1002/ agj2.20304
Liu, Q., X. Wu, J. Ma, B. Chen and C. Xin. 2015. Effects of delaying transplanting on agronomic traits and grain yield of rice under mechanical transplantation pattern. PLoS one, 10(4): e0123330. https://doi.org/10.1371/journal. pone. 0123330

Liu, Q., X. Zhou, J, Li and C. Xin. 2017. Effects of seedling age and cultivation density on agronomic characteristics and grain yield of mechanically transplanted rice. Sci. Rep., 7(1): 1-10. https://doi.org/10.1038/s41598-01714672-7

Mann, R.A. and M. Ashraf. 2001. Improvement of Basmati and its Production Practices in Pakistan. In: Specialty Rice of the World: Breeding, Production and Marketing. Chaudhary, R.C., D.V. Tran and R. Duffy (eds.). Food and Agricultural Organization of the United Nations, Rome. pp: 129-148.

Nakano, H., S. Morita, H. Kitagawa, H. Wada and M. Takahashi. 2012. Grain yield response to planting density in forage rice with a large number of spikelets. Crop Sci., 52(1): 345-350. https://doi.org/10.2135/cropsci2011.02.0071

Ottis, B.V. and R.E. Talbert. 2005. Rice yield components as affected by cultivar and seeding rate. Agron. J., 97(6): 1622-1625. https://doi. org/10.2134/agronj2005.0123

Malik, R.K., B.R. Kamboj, M.L. Jat, H.S. Sidhu, A. Bana, V. Singh, Y.S. Saharawat, A. Pundir, R.D. Sahnawaz, T. Anuradha, N. Kumaran and R. Gupta. 2011. No-till and unpuddled mechanical transplanting of rice. Operational Manual, Cereal Systems Initiative for South Asia, New Delhi, India.

Rani, T.S. and K. Jayakiran. 2010. Evaluation of different planting techniques for economic feasibility in rice. Elect. J. Environ. Agric. Food Chem., 9: 150-153.

Sarwar, N., M. Maqsood, S.A. Wajid and M. Anwar-ul-Haq.2011.Impact of nursery seeding density, nitrogen, and seedling age on yield and yield attributes of fine rice. Chil. J. Agric. Res., 71(3): 343-349. https://doi.org/10.4067/ S0718-58392011000300001

Shinde, G.J., V.S. Pandit and J.S. Kadam. 2018. Review paper on development of rice transplanter. Iconic Res. Eng. J., 2: 63-65.

Shu, S., T. Zheng, X. Jia, X. Luo and G. Li. 2009. Effects of nitrogen fertilizer and density on precision hill-direct-seeding rice I-yield 
formation characteristics. Chin. Agric. Sci. Bull., 25: 142-146.

Srinivasulu, K., R. Veeraraghavaiah and K. Madhavi. 1999. Growth performance of rice hybrids under different methods and densities of planting. Crop Res., 18(1): 1-7.

Steel, R.G.D., J.H. Torrie and D.A. Dickey. 1997. Principles and Procedures of Statistics: A Biometrical Approach. 3rd ed. McGraw Hill Book Co. Inc. New York. pp. 400-428.

Wang, D., S. Chen, Z. Wang, C. Ji, C. Xu, X. Zhang and B.S. Chauhan. 2014. Optimizing hill seeding density for high-yielding hybrid rice in a single rice cropping system in south China. PLoS One, 9(10): e109417. https://doi. org/10.1371/journal.pone.0109417

Wang, M.M., Z.W. Liang, F. Yang, H.Y. Ma, L.H. Huang and M. Liu. 2010. Effects of number of seedlings per hill on rice biomass partitioning and yield in a saline-sodic soil. J. Food Agric. Environ., 8: 628-633.

Yang, J.C., H. Zhang and J.H. Zhang. 2012. Root morphology and physiology in relation to the yield formation of rice. J. Integr. Agric., 11(6): 920-926. https://doi.org/10.1016/S20953119(12)60082-3

Yu, L.H., Y.F. Ding, Y.F. Xue, Q.H. Ling and Z.H. Yuan. 2006. Factors affecting rice seedling quality of mechanical transplanting rice. Transact. Chinese Soc. Agric. Eng., 22: 73-78. 